\title{
On the Change in the Mode of the Aggregation of Sake Yeasts with Cellulose by the Chemical Modification of the Cell Surface Components of Sake Yeasts
}

\author{
Nobuo Sugano,* Hiroichi Akiyama and Kikuo Noshiro \\ Research Institute of Brewing, Tax Administration Agency, Kita-ku, Tokyo \\ Received September 6, 1974
}

\begin{abstract}
The changes in mode of the aggregation of Sake yeasts with cellulose by treatments with various reagents which extract the mannan-protein complex or modify ionized groups on the yeast cell surface was studied. The treatments with the disinfectants such as $70 \%$ ethanol and $0.1 \%$ mercuric hydrochloride had no effect on the aggregation. In the treatment with dilute $\mathrm{NaOH}$, trypsin, papain and ethylendiamine, which have generally been known as the reagents which extract the mannan-protein complex on the cell surface of yeasts, the aggregation character disappeared or lowered, therefore it was supposed that the mannan-protein complex on the cell surface participated with the aggregation character. The modification of phosphate groups the cell surface with uranyl nitrate and carboxyl groups with 1,2-epoxypropane and methanolic$\mathrm{HCl}$ had no effect on the aggregation. The modification of amino groups on the cell surface with $\mathrm{HNO}_{2}$ and chloramine $\mathrm{T}$ eliminated completely the aggregation character. From above results, it was assumed that the amino groups in the protein of cell surface participated in the aggregation of Sake yeasts with cellulose.
\end{abstract}

Two types of surface appearance at the end of the fermentation of Sake mash were observed. One is the formation of a thick yeast cover on the top of the mash and the other is the smooth surface of the mash without yeast cover.

It was previously ${ }^{1 \prime}$ demonstrated that these phenomena were influenced by the characters of the yeast strains, whether or not cells aggregate with the cell walls free from the endosperm of rice kernels by the digestion with mold enzymes in Sake mash. That is to say, the yeast cells which aggregated with the cell walls formed a thick yeast cover by floating to the surface of the Sake mash with fermenting $\mathrm{CO}_{2}$ foams, and showed the slow fermentation in the mashes at the end because the cells were separated from the fermentation system. ${ }^{2}$ On the other hand, the strains which did not aggregate with the cell walls dispersed throughout the fermentation and indicated the normal

* Present address: Bureau, Sendai, Japan. fermentation in Sake mashes. ${ }^{2}$

The yeast cells which aggregated with the cell walls free from the endosperm of rice kernels, also aggregated with the fiber of filter paper or cellulose powder. ${ }^{3}$ The aggregation phenomena of yeasts with cellulose were similar to the flocculation of brewer's yeasts. It has been considered that the nature of a brewer's yeast to flocculate is due to the biochemical property of the cell wall. Therefore, the approach of the studies on the mechanism of the flocculation of brewer's yeasts may give some suggestions for the study on the aggregation of Sake yeasts with cellulose.

Eddy ${ }^{4}$ destroyed flocculating property of brewer's yeasts by treating the cells with papain. He concluded that the digested portion on the cell wall consists of the mannanprotein complex from analysis of the liberated components by the digestion. Lindquist ${ }^{51}$ has demonstrated that the tendency toward a rapid flocculation is attributable to the presence of ionized groups on the cell surface, and that the most important in this conection are the 
anionic groups of either nucleic or carboxylic acid. Jansen and Mendlick $^{6}$ have shown that the yeast cell surface is negatively charged at $\mathrm{pH}$ levels above 2.3 such as in wort, beer, buffer solution and water. Sumino ${ }^{7)}$ and Momose ${ }^{8)}$ examined the electrical charge of Sake yeasts by the method of boundery moving electrophoresis, and has shown that the sign of the electrical charge reserved at $\mathrm{pH}$ between 3 and 4 .

Authers $^{3)}$ indicated that the mechanism of the aggregation of Sake yeasts with cellulose was different from that of the flocculation of brewer's yeasts, and speculated that the protein of yeast cell surface played a important part in the aggregation of Sake yeasts with cellulose.

In the present paper, further studies were attempted to know the change of the aggregation of Sake yeasts with cellulose when treated with the reagents which solubilized the mannanprotein complex in the cell surface, and the change of the aggregation and the electrical charge when modified the ionized groups in the cell surface of Sake yeasts.

\section{MATERIALS AND METHODS}

1. Strain used and culture condition. Aggregating Sake yeasts with cellulose: A-63 and S-23 strains. Non-aggregating Sake yeast: Kyokai No. 7 strain. These yeasts were cultured in koji extract (Balling 10) for 10 days at $15^{\circ} \mathrm{C}$.

2. Method of measuring aggregation. After culture, yeast cells were washed three times with distilled water. Four $\mathrm{ml}$ of distilled water was placed into a $10 \mathrm{ml}$ test tube (to fit Shimazu spectrophotometer, Spectronic 20), to which were added washed yeast cells to the optical density at $660 \mathrm{~nm}$ of 0.4 , followed by the addition of $10 \mathrm{mg}$ of the powdery cellulose. The mixture was shaken and then allowed to stand for $2 \mathrm{hr}$. The test tube was shaken and after 5 min the optical density (A) at $660 \mathrm{~nm}$ was measured. As a control, the optical density (B) of the mixture without yeast cells was measured in the same way as above.

The degree of aggregation strength was expressed as follows

$$
\text { Aggregation rate }(\%)=(1-(A-B) / 0.4) \times 100
$$

3. Method of treatment with various reagents

1) Sterilizers. Suspension of cells (5 mg dry weight) in $5 \mathrm{ml}$ of $75 \%$ ethanol or $0.1 \%$ mercuric hydrochloride placed into the test tube were allowed to stand for $30 \mathrm{~min}$.

2) $\mathrm{NaOH}$. Washed cells ( $25 \mathrm{mg}$ dry weight) were suspended in $100 \mathrm{ml}$ of each solution in $0.05 \mathrm{~N}, 0.1 \mathrm{~N}$, $0.2 \mathrm{~N}$ or $0.3 \mathrm{~N} \mathrm{NaOH}$, allowing to stand for $30 \mathrm{~min}$.

3) Trypsin. Suspension of cells ( $25 \mathrm{mg}$ dry weight) in $100 \mathrm{ml}$ of $0.02 \mathrm{M}$ Tris- $\mathrm{HCl}$ buffer, $\mathrm{pH} 8.0$ containing $20 \mathrm{mg}$ or $200 \mathrm{mg}$ trypsin (3 Crystalline, Seikagaku Kogyo Co., Ltd.) were allowed to stand for chosen period of time $(30,60,120$ and $240 \mathrm{~min})$ at $30^{\circ} \mathrm{C}$.

4) Papain. Suspension of cells ( $25 \mathrm{mg}$ dry weight) in $100 \mathrm{ml}$ of $0.02 \mathrm{M}$ Tris- $\mathrm{HCl}$ buffer, $\mathrm{pH} 7.6$ containing $50 \mathrm{mg}$ papain (Tokyo Kasei Kogyo Co., Ltd.) were allowed to stand for $20 \mathrm{~min}$ at $30^{\circ} \mathrm{C}$.

5) Ethylendiamine. Washed cells $(20 \mathrm{mg}$ dry weight) were suspended in $5 \mathrm{ml}$ of anhydrous ethylendiamine for 3 days at $37^{\circ} \mathrm{C}$ as the method of Northcote. ${ }^{9)}$

After treatment all cells were washed three times with distilled water, and the degree of aggregation strength was measured by the spectrophotometric method or observed by the microscope.

\section{Method of chemical modification}

1) Uranyl nitrate. Washed cells (10 mg dry weight) were suspended in $5 \mathrm{ml}$ of $10^{-2} \mathrm{M}$ uranyl nitrate solution for $30 \mathrm{~min}$ at $30^{\circ} \mathrm{C}$ as the method of Lycette. ${ }^{10}$

2) 1,2-Epoxypropane. Washed cells at the concentration of $5 \times 10^{7} / \mathrm{ml}$ were suspended in $5 \mathrm{ml}$ of $0.05 \mathrm{M}$ acetate buffer, $\mathrm{pH} 4.5$ containing $5 \% 1$,2-epoxypropane over night at $30^{\circ} \mathrm{C}$ as described by Mill.11)

3) Methanolic- $\mathrm{HCl}$. Washed cells $(10 \mathrm{mg}$ dry weight) were suspended in $10 \mathrm{ml}$ of methanol containing $0.1 \mathrm{~N} \mathrm{HCl}$ for $50 \mathrm{~min}$ at $58^{\circ} \mathrm{C}$. In control experiments the cells were treated separately with methanol and with $0.1 \mathrm{~N} \mathrm{HCl}$.

4) Nitrous acid. Nitrous acid was prepared as follows. $6 \mathrm{~g}$ of $\mathrm{NaNO}_{2}$ was added in $5 \mathrm{ml}$ of acetic acid, which was fieled up to $40 \mathrm{ml}$ with distilled water. Washed cells (10 mg dry weight) were suspended in 10$\mathrm{ml}$ nitrous acid for $3 \mathrm{hr}$ at $5^{\circ} \mathrm{C}$.

5) Chloramine $T$. Washed cells (10 $\mathrm{mg}$ dry weight) were suspended in $10 \mathrm{ml}$ of $1 \%(\mathrm{w} / \mathrm{v})$ chloramine $\mathrm{T}$ aqueous solution for $6 \mathrm{hr}$ at $37^{\circ} \mathrm{C}$.

6) $I_{2}$. Washed cells ( $10 \mathrm{mg}$ dry weight) were suspended in $10 \mathrm{ml}$ of $0.038 \% \mathrm{I}$ solution, which was adjusted $\mathrm{pH}$ to 3.2 by $0.01 \mathrm{~N} \mathrm{HCl}$, containing $0.033 \% \mathrm{KI}$ for $4 \mathrm{hr}$ at $25^{\circ} \mathrm{C}$.

7) $P C M B$ (p-chloromercuric-benzoic acid). PCMB solution was prepared as follows. Solution A: $2.2 \mathrm{~g}$ of sodium hexamethaphosphate was dissolved in $50 \mathrm{ml}$ of distilled water, followed by the addition of $1 \mathrm{ml}$ in $1 \mathrm{~N} \mathrm{HCl}$. Solution B: $20 \mathrm{mg}$ of PCMB was dissolved in $1 \mathrm{ml}$ in $1 \mathrm{~N} \mathrm{NaOH}$. Solutions of $\mathrm{A}$ and $\mathrm{B}$ were mixed and fieled up to $100 \mathrm{ml}$ with distilled water. 
Washed cells ( $4 \mathrm{mg}$ dry weight) were allowed to react in $30 \mathrm{ml}$ of the mixed solution for $30 \mathrm{~min}$ at $20^{\circ} \mathrm{C}$.

After treatment all cells were washed three times with distilled water, and the degree of aggregation strength was measured by the spectrophotometric method or observed by a microscope.

5. Measurement of the electrophotoretic mobility The electrophotoretic mobility of intact cells and cells treated to modify the surface groups were measured as described by Momose. ${ }^{8)}$

\section{RESULTS}

1. Change in the mode of the aggregation of Sake yeasts with cellulose by the treatment of various reagents

The results are shown in Table I. Aggregation rate decreased slightly by the treatment with $75 \%$ ethanol and $0.1 \%$ mercuric hydrochloride, but little change in the aggregation was observed by microscope. Therefore, it was recognized that life or death of yeast cells had no relation to the aggregation with cellulose.

By the treatment of cells with $0.05 \mathrm{~N} \mathrm{NaOH}$, aggregation rate decreased to some extent for

Table I. The Change of Aggregation of

Sake Yeasts with Cellulose by the Treatment of Sake Yeasts with Various Reagents

Numerical values show aggregation rate.

\begin{tabular}{cccc}
\hline Strains & \multicolumn{2}{c}{$\begin{array}{c}\text { Aggregating } \\
\text { strains }\end{array}$} & $\begin{array}{c}\text { Non-ag- } \\
\text { gregating } \\
\text { strains }\end{array}$ \\
\cline { 2 - 4 } Treatment & A-63 & S-23 & $\begin{array}{c}\text { Kyokai } \\
\text { No. } 7\end{array}$ \\
\hline Control & 75 & 50 & 7 \\
Ethanol (70\%) & 70 & 52 & 7 \\
Mercuric chloride & & & \\
$(0.1 \%)$ & 65 & 47 & 7 \\
$0.05 \mathrm{~N}$ & 57 & 30 & 5 \\
NaOH 0.1 N & 3 & 2 & 1 \\
$0.2 \mathrm{~N}$ & 1 & 1 & 0 \\
$0.3 \mathrm{~N}$ & 1 & 0 & 0 \\
$30 \mathrm{~min}$ & 56 & 35 & 6 \\
Trypsin $60 \%$ & 39 & 25 & 4 \\
$(0.02 \%) 120 "$ & 36 & 20 & 4 \\
$240 "$ & 33 & 19 & 3 \\
$(0.2 \%) 240 "$ & 15 & 9 & 1 \\
Papain & - & - & - \\
Ethylendiamine & - & - & - \\
\hline
\end{tabular}

- : No aggregation (as observed by microscope) both A-63 and S-23 strains, but it was found by microscopic observation that the aggregation still remained. In the case of concentration over $0.1 \mathrm{~N} \mathrm{NaOH}$, both cells of $\mathrm{A}-63$ and S-23 strains lost their ability to aggregate with cellulose.

The treatment of the cells of A-63 and S-23 strains with trypsin at the concentration of $0.02 \%(\mathrm{w} / \mathrm{v})$ for $240 \mathrm{~min}$ resulted in the decrease of about $60 \%$ in aggregation rate, but by microscopic observation the aggregation character was seen to be maintained to some extent. In the case of the treatment at the concentration of $0.2 \%(\mathrm{w} / \mathrm{v})$ for $240 \mathrm{~min}$, the aggregation character was completely eliminated. In the treatment with papain and ethylendiamine, the cells of A-63 and S-23 strains lost their ability to aggregate with cellulose.

The treatment of the cells of Kyokai No. 7 strain with any reagent described above, had no effect on the aggregation character with cellulose, remaining without aggregation.

2. The change of the electrophoretic mobility and the aggregation of yeast cells by the treatment to modify the surface groups

Table II. The Change of Aggregation of Sake Yeasts with Cellulose by the Chemical MODIFICATION OF IONIZED GROUPS on Cell Surface

Numerical values show aggregation rate.

\begin{tabular}{lccc}
\hline & \multicolumn{2}{c}{$\begin{array}{c}\text { Strains } \\
\text { strains }\end{array}$} & $\begin{array}{c}\text { Non-ag- } \\
\text { gregating } \\
\text { strain }\end{array}$ \\
\cline { 2 - 4 } Treatment & A-63 & S-23 & $\begin{array}{c}\text { Kyokai } \\
\text { No. 7 }\end{array}$ \\
\hline Control & 75 & 50 & 7 \\
Uranyl nitrate & 68 & 48 & 6 \\
1,2-Epoxypropane & & & \\
\multicolumn{1}{c}{$5 \%$} & 62 & 40 & 5 \\
12\% & 60 & 38 & 5 \\
Hethanol & 55 & 36 & 5 \\
Methanolic HCl & 70 & 50 & 6 \\
1\% Chloramine T & 58 & 35 & 4 \\
HNO & 1 & 1 & 1 \\
$\mathrm{I}_{2}$ & + & 1 & 2 \\
$\mathrm{PCMB}^{2}$ & + & + & - \\
\end{tabular}

t: Aggregation.

-: No aggregation (as observed by microscope) 
After treatment the change in the mode of the aggregation of Sake yeasts with cellulose are shown in Table II. The treatment of the cells of A-63, S-23 and Kyokai No. 7 strains with uranyl nitrate had no effect on the aggregation with cellulose. After treatment the change of the $\mathrm{pH}$-mobility curves of cells are shown in Fig. 1. There were little change in the pHmobility curves of Kyokai No. 7 strain, but the mobility curve of treated cells of A-63 strain decreased as compared with that of normal cells.

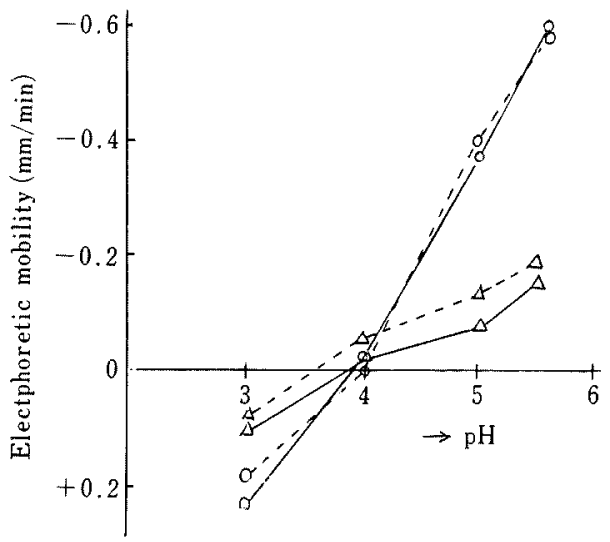

FIG. 1. The pH-Mobility Curves for Normal and Uranyl Nitrated-treated Cells of Sake Yeasts.

O-.. , normal Kyokai No. 7; ○-O, modified Kyokai No. $7 ; \triangle--\triangle$, normal A-63; $\triangle-\triangle$, modified A-63.

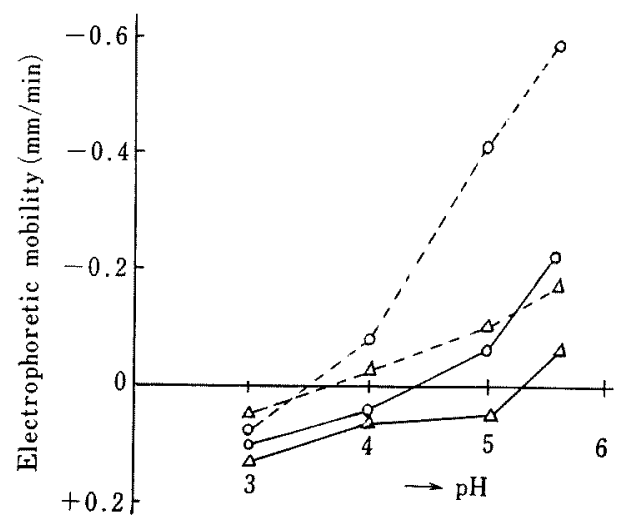

FIG. 2. The pH-Mobility Curves for Normal and $5 \%$ 1,2-Epoxypropane-treated Cells of Sake Yeasts. O---O, normal Kyokai No. 7; O-O, modified Kyokai No. $7 ; \triangle--\triangle$, normal A-63; $\triangle-\triangle$, modified A-63.
The treatment of the cells of A-63 and S-23 strains with $5 \%$ and $12 \%$ 1, 2-epoxypropane resulted in a some decrease of aggregation rate, but under microscope no difference observed between the aggregation of the treated cells and normal cells with cellulose. In the case of Kyokai No. 7 strain also, after treatment there was no effect on the aggregation character. The $\mathrm{pH}$-mobility curves of $5 \% 1$, 2-epoxypropane-treated cells and normal cells of both strains are shown in Fig. 2. The slope of pH-mobility curves of treated cells of both A-63 and Kyokai No. strains decreased as compared with that of normal cells of respective strains. The slope of $\mathrm{pH}$-mobility curve decreased at $\mathrm{pH} 4.0 \sim 5.6$ more in Kyokai No. 7 strain than in A-63 strain.

The effect on the aggregation character due to the treatment with methanolic- $\mathrm{HCl}$ was the same as the result of the treatment with $1,2-$ epoxypropane. In the control experiment of the treatment with methanol and $0.1 \mathrm{~N} \mathrm{HCl}$, $0.1 \mathrm{~N} \mathrm{HCl}$ did not influence aggregation rate for any strain, but methanol lowered the aggregation rate of A-63 and S-23 strains at the same extent as the treatment with methanolic$\mathrm{HCl}$. Therefore, it may be assumed that the decrease of the aggregation rate is due to the effect of methanol.

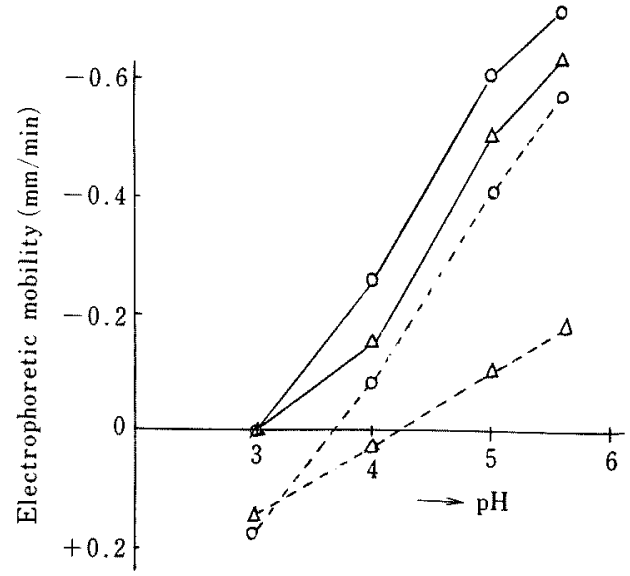

FIG. 3. The pH-Mobility Curves for Normal and Chloramine T-treated Cells of Sake Yeasts.

○-- $\bigcirc$, normal Kyokai No. 7; O- 0 , modified Kyokai No. $7 ; \triangle--\triangle$, normal A-63; $\triangle-\triangle$, modified A-63. 
In the treatment with chloramine T, A-63 and $\mathrm{S}-23$ strains lost completely their ability to aggregate with cellulose, but there was no change on the aggregation character of Kyokai No. 7 strain. Figure 3 shows the change of the electrophoretic mobilities of treated cells and normal cells at various pH's. The increase of mobilities of the negative charge on treated cells at $\mathrm{pH} 3.0 \sim 5.6$ was recognized at both A-63 and Kyokai No. 7 strains. The mobility of treated cells of A-63 strain at $\mathrm{pH}$ 5.6 was 1.7 times as large as that of Kyokai No. 7 strain.

The change of $\mathrm{pH}$-mobility curve of treated cells with $\mathrm{HNO}_{2}$ was the similar to the result of treated cells with chloramine T (Fig. 4).

The young-aged cells of A-63 strain cultured for 4 days at $15^{\circ} \mathrm{C}$, which do not aggregate with cellulose, were treated with chloramine $\mathrm{T}$ and $\mathrm{HNO}_{2}$, and the electrophoretic mobilities of treated cells at various $\mathrm{pH}$ values were compared with those of old-aged cells of A-63 strain cultured for 10 days at $15^{\circ} \mathrm{C}$. The results are shown in Figs. 5 and 6.

As to normal cells, there were no differences between the electrophoretic mobilities of the young cells and old cells, but in the case of the treated cells, the increase of amounts of the negative charge was larger for the old cells than for the young cells at $\mathrm{pH} 3.0 \sim 5.6$.

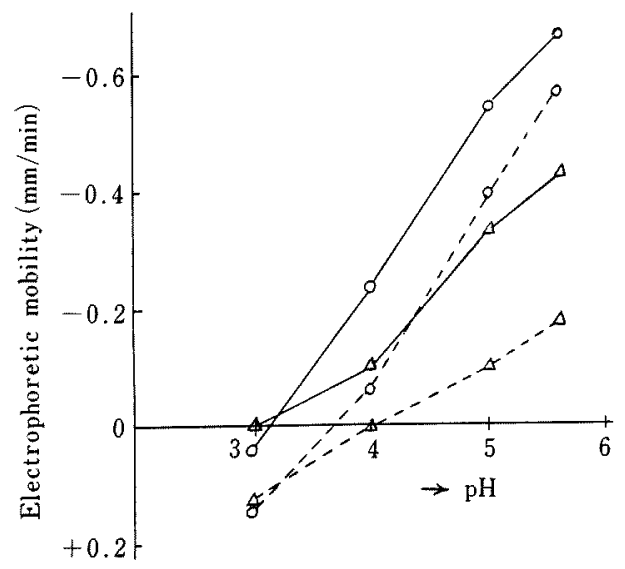

Fig. 4. The pH-Mobility Curves for Normal and $\mathrm{HNO}_{2}$-treated Cells of Sake Yeasts.

O---O, normal Kyokai No. 7; ○- 0 , modified Kyokai No. $7 ; \triangle--\triangle$, normal A-63; $\triangle-\triangle$, modified A-63.

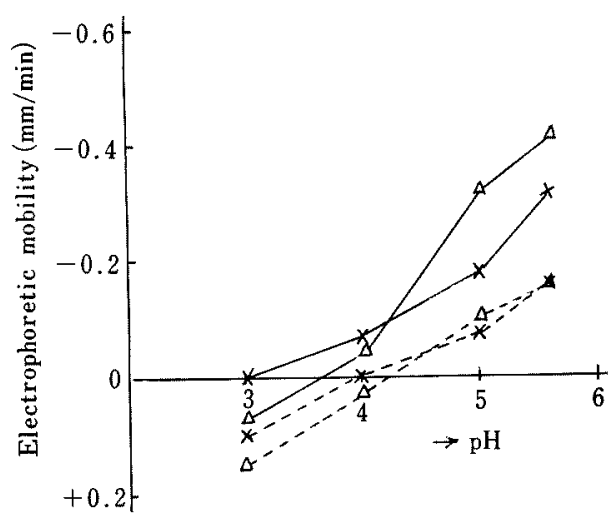

FIG. 5. The pH-Mobility Curves for Normal and $\mathrm{HNO}_{2}$-treated Cells of Sake Yeast A-63 Strain.

$\triangle--\triangle$, normal A-63 (cultured for 10 days); $\triangle-\triangle$, modified A-63 (cultured for 10 days); $\times-.-\times$, normal A-63 (cultured for 4 days); $\times-\times$, modified A-63 (cultured for 4 days).

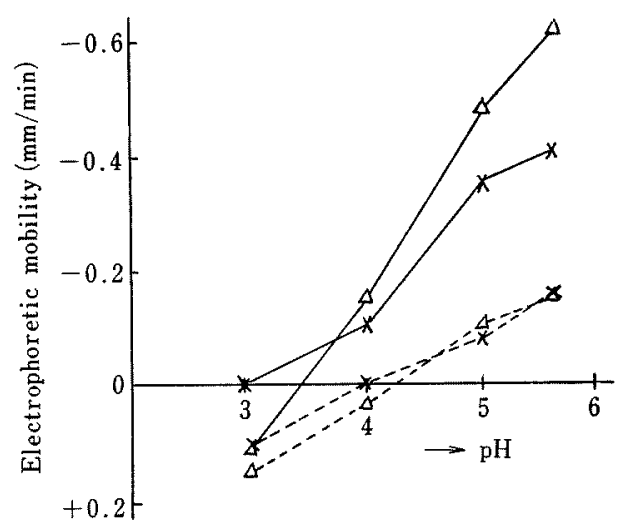

FIG. 6. The pH-Mobility Curves for Normal and Chloramine T-treated Cells of Sake Yeast A-63 Strain. $\triangle--\triangle$, normal A-63 (cultured for 10 days); $\triangle-\triangle$, modified A-63 (cultured for 10 days); $\times$-.- $\times$, normal A-63 (cultured for 4 days); $x-x$, modified A-63 (cultured for 4 days).

The treatment of the cells of A-63, S-23 and Kyokai No. 7 strains with $\mathrm{I}_{2}$ and PCMB had no influence on the aggregation character with cellulose.

\section{DISCUSSION}

In the previous paper, ${ }^{3)}$ it was assumed that from studies on the effect of various conditions on the aggregation of Sake yeasts with cellulose, the protein fraction in the mannan- 
protein complex present on the outer surface of the cell wall was related to the aggregation.

The mannan-protein complex on the brewer's yeast cell surface was digested by the treatment with papain ${ }^{4)}$ and trypsin. ${ }^{12}$ Kijima ${ }^{13)}$ indicated that flocculent brewer's yeasts became non-flocculent when treated with $0.5 \mathrm{~N} \mathrm{NaOH}$ for $15 \mathrm{~min}$. Northcote ${ }^{9)}$ used anhydrous ethylendiamine as milder extraction procedure of the mannan-protein complex than $\mathrm{NaOH}$. Lyons $^{12)}$ recognized that the removal of the mannan-protein complex by the treatment with anhydrous ethylendiamine destroyed the flocculation character of brewer's yeasts.

In the treatment of cells of the aggregating Sake yeasts with cellulose, such as A-63 and S-23 with $\mathrm{NaOH}$, papain, trypsin and anhydrous ethylendiamine, their cells lost the ability to aggregate with cellulose, nonaggregating Sake yeast as Kyokai No. 7 remained to be non-aggregating. Therefore, it is further speculated that the factor participating in the aggregation of Sake yeasts with cellulose exist in the mannan-protein complex of the cell surface.

It has been generally considerd that there were amino groups, carboxylic groups and phosphate groups as the surface ionogenic groups of the cell. Rothstein ${ }^{14)}$ reported that uranyl ion was linked by the phosphate groups on the cell surface. Lycette ${ }^{101}$ recognized that the flocculation character of brewer's yeasts was lost by the treatment with uranyl nitrate. Momose $^{15)}$ has speculated that the phosphate groups of the yeast cell surface are of importance on the aggregation of yeast by lactbacilli because the aggregation lowered remarkably in the treatment of yeast with uranyl nitrate.

1, 2-Epoxypropane have been used for the esterification of protein carboxylic groups. Mill $^{11)}$ observed that the flocculation character of yeast cells was lost by the treatment with $5 \%$ 1, 2-epoxypropane solution. Timakova ${ }^{16)}$ carried out the methylation with methanolic$\mathrm{HCl}$ for modification of carboxylic groups in the cell surface of $E$. coli, and Gittens ${ }^{17)}$ carried out the esterification with methanolic- $\mathrm{HCl}$ for the cells of Aerobacter aerogenes.
$\mathrm{HNO}_{2}$ has been used for the modification of amino groups. It has been generally known that chloramine $T$ can be used for the modification of amino groups, $I_{2}$ was used for the modification of $\mathrm{SH}$ groups and PCMB was used for the modification of S-S groups.

Haydon $^{18)}$ has shown that the measured values by the electrophoretic mobility of cell indicate charge density which exists at a depth of $10 \AA$ on the cell surface. There was little difference in the slope of the $\mathrm{pH}$-mobility curve of normal cells and uranyl nitratetreated cells of Kyokai No. 7 strain between $\mathrm{pH}$ 3.0 and 5.6. Therefore, it is not considered that free phosphate groups are present in the superficial layer of cell walls. On the other hand, in the case of A-63 strain, it is assumed that free phosphate groups are located at the superficial layer of cell walls because the $\mathrm{pH}$ mobility curve of treated cells was different from that of normal cells. However, as there was no change in the aggregation character after a treatment with uranyl nitrate, it is assumed that the phosphate groups have no connection with the aggregation character.

The carboxylic groups in protein are those of the side chain of glutamic acid and asparatic acid residue groups or are those of the termination of polypeptide chain, ${ }^{19)}$ and therefore after the modification of carboxylic groups with $5 \%$ 1, 2-epoxypropane, the larger decrease in the slope of the pH-mobility curve of Kyokai No. 7 strain than that of A-63 strain indicates the possibility that more acidic amino acids are present in the superficial layer of cell walls of Kyokai No. 7 strain than in that of A-63 strain. As the modification for the carboxylic groups had no effect on the aggregation character, it is not considered that the carboxylic groups in the surface layer of the cell walls are related with the aggregation character of Sake yeasts with cellulose. The treatment with $\mathrm{I}_{2}$ and PCMB also had no effect on the aggregation character, therefore, both $\mathrm{S}-\mathrm{H}$ and $\mathrm{S}-\mathrm{S}$ groups in the surface layer of cell walls appear not to be related to the aggregation.

Though there are $\varepsilon$-amino group in lysine residue and end-amino group in polypeptide 
chain as amino groups in protein, it is commonly accepted that there is very little endamino groups as compared with the $\varepsilon$-amino groups in lysine residue. ${ }^{19}$ ) By the modification of amino groups in cells, the increase in the slope of the $\mathrm{pH}$-mobility curve was larger for old-aged cells of A-63 strain, which showed the aggregation character with cellulose, than the young-aged cells of A-63 and Kyokai No. 7 strain. It may be considered that the amounts of $\varepsilon$-amino groups in lysine residue are present more at the surface layer in the old-aged cells of A-63 strain than at that in the young-aged cells of A-63 and Kyokai No. 7 strain.

As the aggregation character of A-63 strain with cellulose was much eliminated by the modification for amino groups in cells, it is speculated that the factor to participate in the aggregation is $\varepsilon$-amino groups of lysine residue in the cell surface of A-63 strain.

\section{REFERENCES}

1) N. Sugano, H. Akiyama and K. Noshiro, Nippon Nogeikagaku Kaishi, 47, 763 (1973).

2) N. Sugano, Y. Goto, K. Kaya, H. Akiyama and
K. Noshiro, J. Soc. Brew Japan, 67, 49 (1972).

3) N. Sugano, H. Akiyama and K. Noshiro, Nippon Nogeikagaku Kaishi, 47, 771 (1973).

4) A. A. Eddy, J. Inst. Brew., 64, 368 (1958).

5) W. Lindquist, ibid., 59, 59 (1953).

6) H. E. Jansen and F. Mendlick, Proc. Eur. Brew. Conv., 1951, p. 59; 1953, p. 143.

7) K. Sumino, H. Kawase, Y. Tani and S. Fukui, J. Ferment. Technol., 44, 594 (1966).

8) H. Momose, K. Iwano and R. Tonoike, J. Gen. Appl. Microbiol., 15, 19 (1969).

9) E. D. Korn and D. H. Northcote, Biochem. J., 75, 12 (1960).

10) R.M. Lycette and L.R. Hedrick, Appl. Microbiol., 10, 428 (1962).

11) P. J. Mill, J. Gen. Microbiol., 35, 61 (1964).

12) T. P. Lyons and J. S. Hough, J. Inst. Brew., 77, 300 (1971).

13) M. Kijima, Pep. Res. Lab. Kirin Brew. Co. Ltd., 7,7 (1964).

14) A. Rothstein, Dise. Frady. Soc., 21, 229 (1956).

15) H. Momose, K. Iwano and R. Tonoike, Nippon Nogeikagaku Kaishi, 43, 119 (1969).

16) N. V. Timakova, Microbiolojiya, 35, 864 (1966).

17) G. J. Gittens and A. M. James, Biochem. Biophys. Acta, 66, 237 (1963).

18) D. A. Haydon, Biochem. Biophys. Acta, 50, 450 (1961).

19) S. Mizushima and S. Akabori, "Chemistry of Protein," Vol. 2, (in Japanese), Kyoritsu Press, 1954, p. $26,27$. 